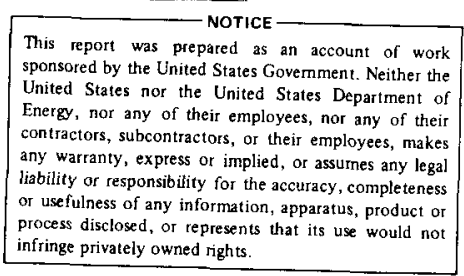

SPE 6763

\title{
A Study of the Structural Control of Fluid Flow within the Cerro Prieto Geothermal Field, Baja California, México
}

\author{
John E. Noble ${ }^{1}$, Alfredo Mañon M. $^{2}$, Marcelo J. Lippmann ${ }^{1}$, \& Paul A. Witherspoon ${ }^{1}$
}

\section{Abstract}

The Lawrence Berkeley Laboratory and the Comision Federal de Electricidad of Mexico are conducting a joint investigation of the Cerro Prieto Geothermal Field, located approximately $35 \mathrm{~km}$ south of Mexicali, Baja California, Mexico, in the Sea of Cortez-Salton Trough.

Recent analyses of various geophysical/electrical logs, temperature logs, production and geochemical data and the subsequently developed preliminary model of the structure of the geothermal system and the distribution of geothermal fluids are presented. Techniques routinely applied to petroleum exploration were successfully used in the development of a preliminary model of this water-dominated system.

Our study indicates the upwelling of geothermal fluids along an east bounding fault from a deep, as yet unexplored source. The fluids dissipate into various sand horizons at various depths. The resulting stratigraphic and fluid flow model is of importance in planning additional developments of the Cerro Prieto Geothermal Field.

\section{Introduction}

The Imperial-Mexicali Valley is recognized as having a potential for large scale production of electrical power from geothermal resources to help satisfy the energy requirements of Southern California and the Mexican states of Sonora and Baja California, North. Estimates of the potential of the Imperial Valley, alone, range from 5000 to $10000 \mathrm{Mwe}^{1,2}$. Exploration has defined various geothermal prospects in the Imperial valley, and consequently several areas are currently being evaluated, e.g.: Brawley, Heber, East Mesa, etc. (Figure 1).

In the Mexicali Valley, exploration for geothermal resources has concentrated south-southeast of the Cerro Prieto Volcano, over a 400 square $\mathrm{km}$ area approximately $35 \mathrm{~km}$ south of Mexicali, Baja California. This area is typified by numerous hot springs, mud volcanos, and fumaroles. The neighboring sierra de los Cucapas, which lie to the west of Cerro Prieto, are the predominate structural feature of the area.
In 1959 exploration for geothermal resources began in this area with photo and field geologic surveys ${ }^{3}$. In the same year three shallow exploratory wells (M$1 \mathrm{~A}, \mathrm{M}-2, \mathrm{M}-2 \mathrm{~A})$ were drilled to depths of $523 \mathrm{~m}, 755 \mathrm{~m}$, and $403 \mathrm{~m}$, respectively. Geophysical investigations were commenced in 1961 with gravimetric and resistivity surveys. These surveys were completed in 1963.

In 1964 four exploration weIls $(M-3, M-4, M-5, M-6)$ were drilled to depths of $2563 \mathrm{~m}, 2006 \mathrm{~m}, 1303 \mathrm{~m}$, and $2040 \mathrm{~m}$, respectively ${ }^{3}$ (Figure 3 ). Well M-3 penetrated Cretaceous Cucapas granodiorite basement at $2532 \mathrm{~m}$. Well M-5 was a discovery well, and from 1966 to 1968, 14 production wells were drilled. The production from these wells, supplemented by production from four of the twelve wells drilled since 1972, supply separated steam to a 75 Mwe power plant. The total production is currently 750 tonne/hr separated steam (at 100 psig) and 2000 tonne/hr separated water. The separated water is piped to a brine waste pond; while in transit to the pond, the water flashes and vents to the pond as steam. Approximately 30 Mwe are lost to the waste pond, and development plans call for future installation of low-pressure turbines to utilize this energy source.

The Cerro Prieto power plant commenced operation in April, 1973. It was the first operational geothermal power plant in Latin America and the first liquiddominated geothermal system to produce commercial amounts of electricity in the Americas. The plant is currently being expanded to 150 Mwe, utilizing production from new and existing standby wells. Development and exploration drilling are continuing, and a target of 400 Mwe has been set for 1982 .

Comision Federal de Electricidad's (CFE) systematic exploration and development of the cerro prieto geothermal resource has resulted in a vast accumulation of data. These data provide a rare opportunity to conduct a case study of the exploitation of a geothermal system. In 1975, a working relationship was established between $\mathrm{CFE}$ and the Lawrence Berkeley Laboratory (LBL) to conduct such a study. In addition, LBL would become a repository for Cerro Prieto data in order to make such data available to the geothermal community. This relationship was formalized in July, 1977 by the signing of an agreement by the governments

References and Illustrations at end of the paper.

1. Lawrence Berkeley Laboratory, University of California, Berkeley, California 94720

2. Comisión Federal Electricidad, Coordinadora General Ejecutiva de Cerro Prieto, Mexicali, B.C., México. 


\section{DISCLAIMER}

This report was prepared as an account of work sponsored by an agency of the United States Government. Neither the United States Government nor any agency Thereof, nor any of their employees, makes any warranty, express or implied, or assumes any legal liability or responsibility for the accuracy, completeness, or usefulness of any information, apparatus, product, or process disclosed, or represents that its use would not infringe privately owned rights. Reference herein to any specific commercial product, process, or service by trade name, trademark, manufacturer, or otherwise does not necessarily constitute or imply its endorsement, recommendation, or favoring by the United States Government or any agency thereof. The views and opinions of authors expressed herein do not necessarily state or reflect those of the United States Government or any agency thereof. 


\section{DISCLAIMER}

Portions of this document may be illegible in electronic image products. Images are produced from the best available original document. 
of Mexico and the United States. Both CFE and LBL hope that the study of Cerro Prieto will be of benefit not only to the participants, but also to the geothermal community, by serving as a model for similar studies of other liquid-dominated geothermal systems.

As a result of recent analyses of geophysical well logs, lithologic logs, temperature, chemical, and production data by CFE and LBL, a preliminary model of the structural control of fluid flow within the Cerro Prieto Geothermal Field is presented in this paper.

Future studies will attempt to evaluate the accuracy and usefulness of this preliminary model with a goal of developing a more complete model that can be used in subsequent evaluation, development and exploration of the Cerro Prieto Geothermal System.

Regional Geology and Lithology

The Cerro Prieto Geothermal Field lies within the Sea of Cortez-Salton Trough, to the east of the Sierra de los Cucapas, a plutonic basement exposure of preJurassic metasediments, Jurassic La Puerta Tonalite, and Cretaceous Cucapas Granodiorite ${ }^{4}$. The Cerro Prieto Volcano is located approximately $6 \mathrm{~km}$ northwest of the center of the field (Figure 4). The $260 \mathrm{~m}$ high rhyodacite cone and associated pyroclastics cover an area of 4 square $\mathrm{km}$. Deformation and alteration of local sediments and the minimal amount of, or lack of; weathering of the volcanic rock imply a late pleistocene or Holocene eruption. Magnetic polarity data limit the date of eruption to within the last 700000 years ${ }^{4}$. Investigators have attributed the origin of the Cerro Prieto rhyodacite to melting of the plutonic cucapas Granodiorite and postulated that the thermal source of the Cerro Prieto Volcano was and continues to be the thermal source of the Cerro Prieto hydrothermal system ${ }^{5}$

The association of surface expressions of thermal sources and subsurface hydrothermal systems is evident at other locations in the sea of Cortez-Salton Trough. Studies have been conducted at the south end of the Salton Sea to evaluate the hydrothermal system associated with the Salton Sea rhyolite domes ${ }^{6}, 7$. South of Cerro Prieto, in the sea of Cortez, oceanographic studies have identified various active seismic and volcanic areas ${ }^{8}$. Hydrothermal systems possibly associated with these regions are, as yet, unexplored.

These thermal and seismic phenomena, as well as the structural sea of Cortez-Salton Trough are manifestations of crustal thinning and continental margin rifting associated with the transition from the East Pacific Rise divergent plate boundary to the transform boundary of the San Andreas Fault System (Figure 2). This rifting is caused by a combination of tensional and right-lateral strike-slip movements that shear away continental material from the North American Plate margin and transfer it to the Pacific Plate ${ }^{7,9}$.

The sediments filling the Imperial-Mexicali Valley represent continuous deposition of alluvium, fanglomerate, lacustrine and deltaic silts, sands and gravels since the Middle to Late Miocene. These sediments were derived from the bordering granitic rocks and metasediments, and from the drainage basins of the Colorado River system. The geology of the Imperial Valley has been described by Dibblee ${ }^{10}$ and his definitions have been used by later investigators to describe the lacustrine and deltaic sediments of the Mexicali valley that are time correlative and lithologically. similar"4. No regional geologic studies of the Mexicali valley are available.

Well M-3 is the only well in the Cerro Prieto Geothermal Field to penetrate through sediments to basement. Alonso and Mooser ${ }^{11}$ reported that the well was drilled through $2532 \mathrm{~m}$ of alluvium, fanglomerate, and fluvial and lacustrine sediments to reach the basement granodiorite. A study by CFE indicated that the basement under $M-7$ is greater than $4.5 \mathrm{~km}^{5}$. A geophysical study by Biehler, et al. ${ }^{12}$, of the northern Sea of Cortez-Salton Trough suggests a maximum depth-to-basement of approximately $6 \mathrm{~km}$ in the center of the Mexicali valley.

The majority of the Cerro Prieto Geothermal wells (Figure 4) are drilled to a depth of approximately $1500 \mathrm{~m}$. The upper $700-800 \mathrm{~m}$ of these wells is predominated by Holocene alluvium and a thick section of grey and brown claystone-siltstone with interbedded sand stringers, probably contemporaneous with the PlioPleistocene Borrego-Brawley formation as described by Dibblee ${ }^{10}$. The section gradually thickens to the south and east. However, between wells $\mathrm{M}-10$ and $\mathrm{M}-53$, and wells M-48 and M-51, a more rapid thickening of the section occurs, possible related to faulting contemporaneous with deposition. The siltstone-claystone section grades with depth to a section of deltaic fine grained, quartz sandstone interbedded with gray calcareous shale and argillite, contemporaneous with the Pliocene Palm Springs formation (Figures 5 and 6 ). The sandstone beds of this deeper section constitute the reservoir rock of the Cerro Prieto Geothermal Field.

The two western most wells: $M-3$ and $M-6$, are not typified by the above description. Both wells have thick section of alluvium and fanglomerates that are absent in the wells to the east and neither well has the quartz sandstone and shale section that is present in the eastern wells. Correlations of lithologic and geophysical logs between wells $M-6$ and $M-9$, and wells M-3 and M-7 infer a facies change between these wells as well as faulting contemporaneous with deposition.

\section{Method of Investigation}

In 1975, an arrangement was made with CFE for LBL to collect available data on the geology, hydrogeology, geochemistry, and reservoir characteristics of the Cerro Prieto Geothermal Field. The data sent to LBL were placed in an open-file data bank. The accumula-tion of these data has continued since 1975 and recently, a report was issued documenting the current holdings of the data bank available to the geothermal community for iridependent study ${ }^{13}$. In addition to establishing the Cerro Prieto data bank, LBL began a project to analyze the Cerro prieto data and from these analyses develop geological, hydrogeological, geochemical, and numerical reservoir models of the Cerro Prieto Geothermal System.

During the second half of 1976, selected geophysical well-logs were digitized. Digitization was done in order to use computer well-log interpretation techniques and auto-correlation methods. Because of the volume of well loq data from Cerro Prieto, computer analysis of the data was judged necessary to expedite their use. Another objective was to evaluate the usefulness of various computer interpretative techniques and auto-correlation methods in developing models of an operating liquid-dominated geothermal field. Currently in use at IBL is an auto-correlation program based on a computer code developed by Rudman and 
Blakely ${ }^{14}$. In addition, programs are being tested that will adjust well-logs for well-bore conditions, enhance through various filters the adjusted logs, make interpretations of the logs applicable to the logging system being used, and examine and interpret the variation of numerical geologic data.

The auto-correlation program, COR4LOG ${ }^{14}$, is a cross correlation method of comparing time series. Given two time series, or two pairs of time series, COR4LOG uses cross correlation to determine the relative displacement and the stretch factor between the series. The measure of similarity between time series can be expressed as:

$$
\begin{aligned}
\phi_{X Y}(S, \tau) & =\frac{\sum_{i=1}^{L_{1}} x_{i} Y_{i+\tau}-L_{1} \bar{X} \bar{Y}_{\tau}}{\left[\left(\sum_{i=1}^{L_{1}} x_{i}^{2}-L_{1} \bar{X}^{2}\right)\left(\sum_{i=1}^{L_{1}} Y_{i+\tau}^{2}-L_{1} \bar{Y}_{\tau}^{2}\right)\right]^{1 / 2}} \\
& \ddot{X}=\frac{1}{L_{1}} \sum_{i=1}^{L_{1}} X_{i} \quad \bar{Y}=\frac{1}{L_{1}} \sum_{i=1}^{L_{1}} Y_{i+\tau}
\end{aligned}
$$

(From Rudman and Blakely ${ }^{14}$ )

where $\phi_{X Y}(S, \tau)$ is a measure of the similarity between time series $X(t)$ of length $L_{1}$ and $Y(t)$ of length $L_{2}$. $S$ is the amount a series is stretched and $\tau$ is the amount a series is shifted. If $\phi_{X Y}(S, \tau)=1, X$ and $Y$ are perfect matches; if $\phi_{X Y}(S, \tau)=0$, they are not correlatable; and if $\phi_{X Y}(S, \tau)=-1$, they correlate in the inverted phase of the series.

In COR4LOG, the longer of the two time series is held fixed as the other series is moved along it and a $\phi_{X Y}(S, \tau)$ is computed at each data point. To allow for stretch between time series, additional values are interpolated into the shorter series at regular intervals. This new series is then moved along the series being held fixed and a $\phi_{X Y}(S, \tau)$ value is again computed at each data point. The amount a series is stretched is operator defined, up to a maximum of the ratio between the time series. The amount of each stretchstep is also operator defined. The stretching and computational procedure continue until the predetermined maximum stretch is reached. The stretch and lag values at which the greatest value of $\phi_{X Y}(S, \tau)$ is computed is the best correlation between the time series. A subroutine plots the time series and draws tie-lines between the series to illustrate results of the cross correlation. Figure 7 shows a plot of the cross correlation between a 61 meter interval (1159 $\mathrm{m}$ to $1220 \mathrm{~m}$ ) of $\mathrm{M}-9(\log 1)$ and a $183 \mathrm{~m}$ interval $(1098 \mathrm{~m}$ to $1281 \mathrm{~m})$ of $M-10(\log 2)$. Both are self potential logs. The plot indicates a maximum correlation coefficient of 0.675 at a lag of 342 data points $(52 \mathrm{~m})$ and a stretch of 1.700. The correlation of four series, two logs from each of two wells, follows the steps described above. The value used to pick the best correlation between the two wells is the sum of the two cross correlation functions computed between identical type logs from the two wells.

Because of the repeated multiplications and additions involved in cross correlation of time series, the auto-correlation program simplifies the cross correlation operation by transforming the series from the time domain to the frequency domain. The series are correlated in the frequency domain and transformed by an inverse Fourier transform to yield the desired cross correlation.

The results of the auto-correlation program were used to corroborate correlations determined by visual log-matching techniques. In some cases, where visual techniques failed to be useful in determining correlations, the results of the auto-correlation program were used exclusively. Utilizing these various methods, major lithologic units below $750 \mathrm{~m}$ were delineated across the Cerro Prieto geothermal field. Attempts have been made to corroborate the well-log derived lithologic delineations with delineations chosen using the lithologic strip charts detailing the well-bore cuttings. There does not appeax to be a good correspondence between the well-logs and their respective lithologic charts. Reexamination of selected cuttings using a binocular microscope, thin sections, and $x$-ray diffraction analysis are being done by the Institute of Geophysics and Planetary Physics at the University of California, Riverside, and may resolve the discrepancies between the well-logs and the Iithologic charts. These data will be incorporated into the geological and hydrogeological models of the Cerro Prieto Geothermal Field.

Analyses of the major lithologic units is continuing. Attempts are being made to subdivide the major units on a progressively finer scale until individual rock units are correlated and various facies changes, unconformities, faults, mineralization zones, and stratigraphic structures are defined.

Figure 8 shows the major lithologic units that have been delineated by manual well-log correlation techniques and the auto-correlation program, COR4LOG. The figure shows only the peripheral wells of the producing field and outlying exploration wells.

The short-normal resistivity, SP, and microresistivity logs from each of the producing wells were used to make, in each of the producing intervals, a sand count and to determine the approximate average porosity of these sands. These data were used to calculate a volumetric value for each producing interval by multiplying the average sand porosity $(\varnothing)$ in the well's producing interval by the interval's effective sand thickness $\left(h_{e}\right)$. Figures $10 a-c$ show the distribution of sand percentages, porosities, and volumetric values in the producing intervals across the field.

The ratio of production (tonne/hr) to effective sand thickness was calculated (Table 1) for each producing well (January, 1977 production data). Figure lod shows the 2.5 ratio contour. The arbitrary division of the field by this contour line appears to correspond with the change from interstitial-controlled production ( $>2.5$ ) to fracture-controlled production $(<2.5)$, inferred from drilling and production data. Because of difficulties in data analysis caused by the irregular distribution of production intervals and by the presence of interstitial and fracture porosity in the reservoir, a quantitative interpretation of the productivity of individual lithologic units is not possible at this time. Studies are in progress, or planned, to help make such an interpretation possible.

In addition to the well-log and production data study, a review was made of the various temperature logs available for each well to determine which of them were most representative of temperature distribution in the Cerro Prieto geothermal reservoir. The selected 
temperature logs were used to construct temperature distribution profiles and these were, in turn, matched against the distribution of the production intervals. Figure 9 shows the temperature distribution and the production intervals in the Field. The isotherms in Figure 9 were derived from a composite of the temperature distribution profiles.

A review of the geochemical data was made to deter mine if there were evident trends that correspond to trends derived from analysis of other field data. The results of this review are presented in Figure lla-c which show the distribution of $\mathrm{Na} / \mathrm{K}$ ratios, $\mathrm{SiO}_{2}$ and $\mathrm{Cl}$ values across the Field. Figure 1ld shows the wells analyzed. A more extensive review and presentation of these data are presented in Mañon, et.al. ${ }^{15}$.

\section{CONCLUSIONS}

1. The reservoir at Cerro Prieto is formed by an interbedded sequence of deltaic sands and shales of variable thickness. These sands and shales; overlain by a $750 \mathrm{~m}$-thick claystone-siltstone caprock, can be divided into four major lithologic units by correlation of three, thick shale beds across the field (Figure 8). The individual units are characterized by an increasing percent of shale in their upper half and an increasing percent of sand in their lower half. The thickness of individual sand beds increases towards the bottom of each unit.

Wells in the southeastern part of the Field were drilled into a fifth unit. This unit is typified by low sand counts, beds of relatively high resistivity, and high temperatures (Figures 8 and 9). It is considered to have predominately fracturecontrolled porosity that permits the upwelling of geothermal fluids.

The correlation of units between:wells have identified different magnitudes of offset, down to the east; 1) $420 \mathrm{~m}$ between $M-10$ and $M-53$; 2) $310 \mathrm{~m}$ between $M-6$ and $M-9$; and, 3) $50 \mathrm{~m}$ between $M-7$ and $M-3$. As a result of these correlations, it is postulated that the Field is bound by two northwest trending normal faults, one to the east between wells $M-10$ and $M-53$, and the other to the west, between wells $M-3$ and $M-7$ and wells $M-6$ and M-9. Both faults are down thrown to the east. Deposition has been contemporaneous with faulting as evidenced by the thickening of the lithologic units towards the east.

2. The review of chemical data by Mañon, et.al. ${ }^{15}$, defined trends that were in general agreement with the structural division of the field into three discrete blocks. The chemical characteristics of block 1 is represented by well M-53. (Figure lla-d), block 2 by the main group of producing wells, and block 3 by well $M-6$. Some disagreement centers around well $\mathrm{M}-3$. Structurally it should be placed in block 3 , chemically in block 2. The origin of fluids from well $\mathrm{M}-3$ is not presently well understood; future hydrogeologic studies may help resolve the disagreement over well $\mathrm{M}-3$.

3. The production intervals have been chosen primarily on the basis of well temperature logs. Common practice at Cerro prieto is to run a slotted liner at the bottom of a well and to produce over an interval of several hundred meters. The correspondence of production intervals to temperature distribution (Figure 9) illustrates this practice.
The isotherm distribution presented in Figure 9 is in essential agreement with the earlier work of Mercado 17. It indicates upwelling of thermal fluid east and southeast of the Field. Mercado postulated a vertical migration of fluids in the center of the Field in addition to upwelling along a bounding fault to the east.

We postulate that the upwelling of fluids is centered to the southeast of the Field, around the intersection of a south bounding fault and the aforementioned east bounding fault. Fluids move vertically along these fault zones until they encounter fracture zones in the lower part of the Cerro Prieto reservoir. These fractured zones allow the fluids to migrate horizontally, as well as vertically, toward the central and northwestern parts of the field. Vertical fluid migration between major lithologic units is controlled by fractures in the shale beds. These fractures open and close as a consequence of regional tectonic activity and chemical precipitation. Consequently the direction of fluid flow varies, somewhat, over time in the reservoir. As the fluids move toward the western part of the Field they migrate vertically and horizontally into porous sands.

West of the Field, cold water influx along the postulated boundary fault, and through subsurface alluvium deposits form a western thermal field boundary.

\section{REFERENCES}

1. Towse, Donald: An Estimate of Geothermal Energy Resources in the Salton Trough, Lawrence Livermore Laboratory, UCRL-51851, (June, 1975).

2. White, D. C. and Williams, D. L.: Assessment of Geothermal Resources in the United States, U.S.G.S. Circular 726, (1975).

3. Alonso, H.: "La Zona Geotermica De Cerro Prieto, Baja California", Soc. Geol. Mexicana Boletin, vol. 29, no. 1, (1966) 17-47.

4. Barnard, F.: Structural Geology of the Sierra De Los Cucapas, N. E. Baja California, Mexico, and Imperial County, California, Ph. D. thesis, University of Colorado, (1968).

5. Reed, M. J.: "Geology and Hydrothermal Metamorphism in the Cerro Prieto Geothermal Field, Mexico", in Proceedings, Second United Nations Symposium on the Development and Use of Geothermal Resources, vol. 1, (1975), 539-547.

6. Helgeson, H. C.: Geologic and Thermodynamic Characteristics of The Salton Sea Geothermal system, Amer. Jr. Sci., vol. 266, (March, 1968), 129-166.

7. Elders, W. A., Rex, R. W., Meidav, T., Robinson, P. T., and Biehler, S.: Crustal spreading in Southern California, Science, vol. 178, (October 6, 1972), 15-24.

8. Lawver, L. A., Williams, D. L., and von Herzen, R. P.: "A Major Geothermal Anomaly in the Gulf of California", Nature, vol. 257, (September 4, 1975), 23-28.

9. Atwater, T.: Implications of Plate Tectonics for the Cenozoic Evolution of Western North America, Geol. Soc. Amer. Bull., vol. 81, (1970), 3513-3536. 
10. Dibblee, T. W., Jr.: "Geology of the Imperial Valley region, California", in Jahns, R. H., ed., Geology of Southern California: California Div. Mines Bull. 170, vol. 1, (1954), 21-28.

11. Alonso, H., and Mooser, F.: El Pozo M-3 del Campo Geotermico del Cerro Prieto, B. C., Mexico, Asoc. Mexicana Geologos Petroleros Bol., vol. 16, (1964), 163-178.

12. Biehler, S., Kovach, R. L., and Allen, C. R.: "Geophysical Framework of the Northern End of Gulf of California Structural Province", in van Andel, T. H., and Shor, G. G., Jr., eds.: Marine Geology of the Gulf of California; AAPG Memoir 3, (1964), 126-143.

13. Lippmann, M. J., Dominquez, B., Wollenberg, H. A., and Witherspoon, P. A.: Open File Data on the Cerro Prieto Geothermal Field, Lawrence Berkeley Laboratory, LBL-6321, (April, 1977).

14. Rudman, A. J., and Blakely, R. F.: Fortran Program WELI for Correlation of Stratigraphic Time Series, Geological Survey Occasional Paper 14, Indiana Geological Survey, Department of Natural Resources, (1976).

15. Mañon, A., Jimenez, M. E., Sanchez, A., Fausto, J. J., Zenizo, C. A., and Mazon, E.: Extensive Geochemical Studies in the Geothermal Field of Cerro Prieto, Mexico, in press, Lawrence Berkeley Laboratory, (1977).

16. Palmer, T. D., Howard, J. H., Lande, D. P.: Geothermal Development of the Salton Trough, California and Mexico, Lawrence Livermore Laboratory, NCRL-51775, (April, 1975).

17. Mercado, S.: "Migración de Flúidos Geotērmicos y Distribución de Temperaturas en el Subsuelo del Campo Geotérmico de Cerro Prieto, Baja California, Mexico", in Proceedings, Second United Nations Symposium on the Development and Use of Geothermal Resources, vol. 1, (1975), 487-494.

Acknowledgement

This work was done under the auspices of the United States Energy Research and Development Administration. 
6 A Study of the Structural Control of Fluid Flow within the Cerro Prieto Geothermal Field, B.C., Mexico SPE 6763

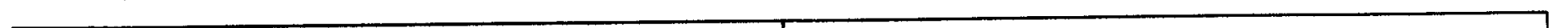

FIGURES NEXT PAGE 


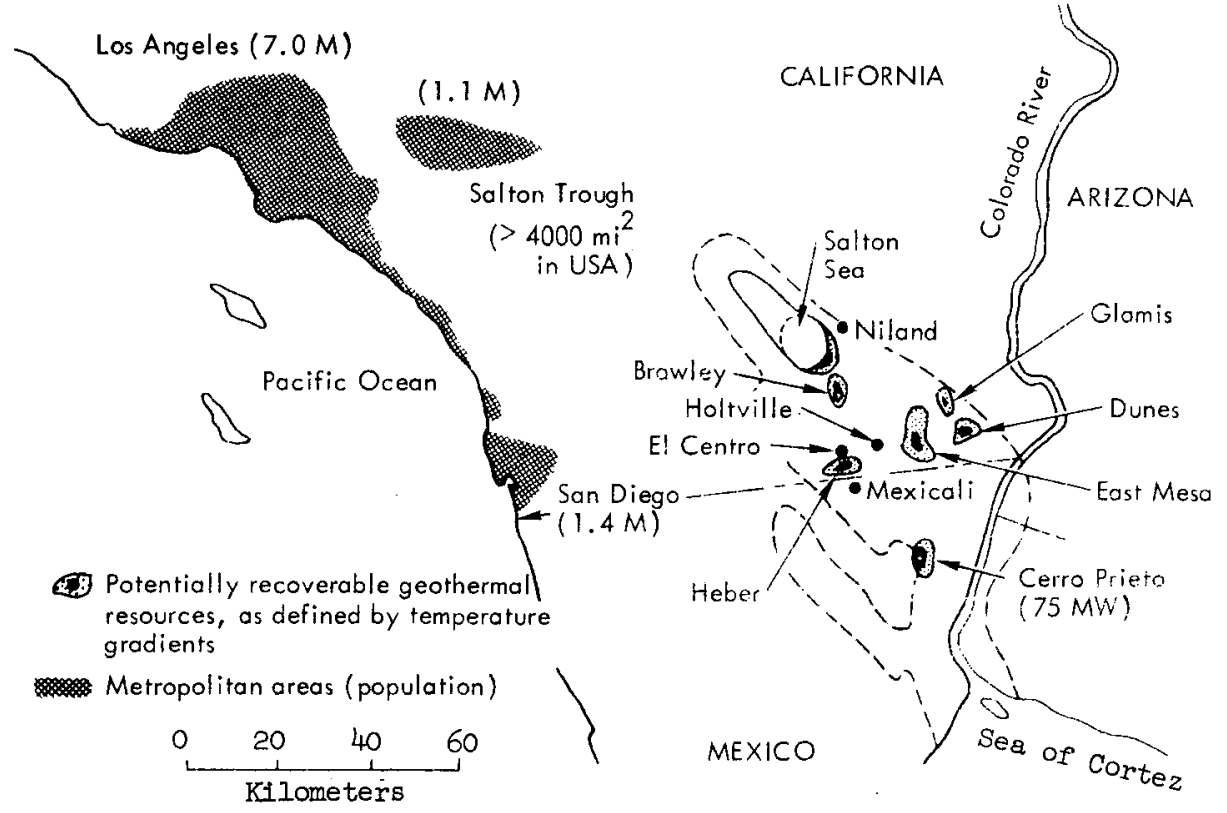

Figure 1. Sea of Cortez-Salton Trough geothermal province and known geothermal resource areas (KGRA); (from Palmer, et.al.16).
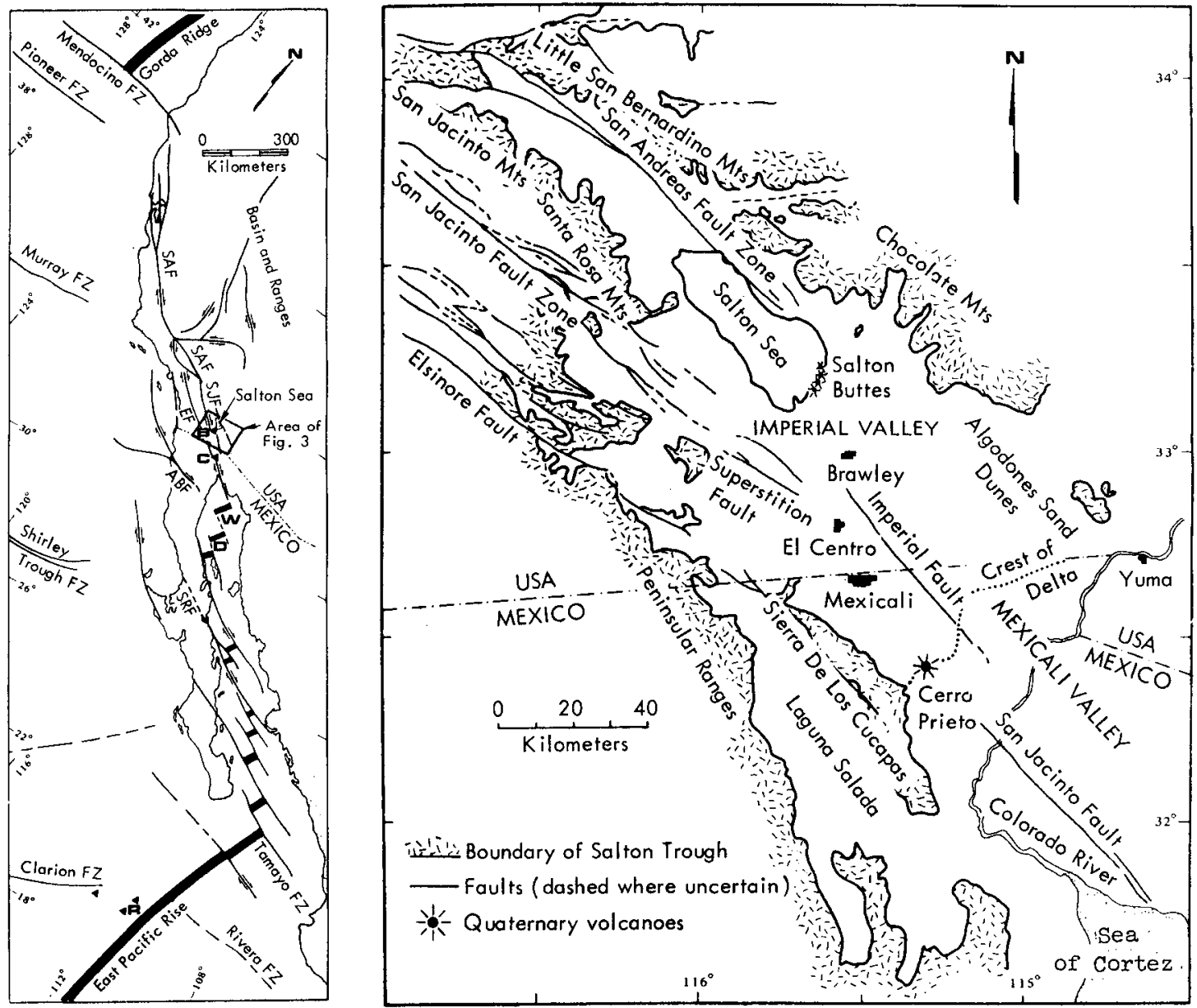

Figure 2. General tectonics of North American Pacific Coast. Included are postulated pull-apart basins between en echelon fault segments in the sea of Cortez: $\mathrm{W}=$ Wagner Basin, $\mathrm{D}=$ Delfin Basin. $\mathrm{A}=$ Holocene Volcanoes: $\mathrm{B}=$ Salton Buttes, $C=$ Cerro Prieto; (from Elders, et.al. ${ }^{7}$ ). 


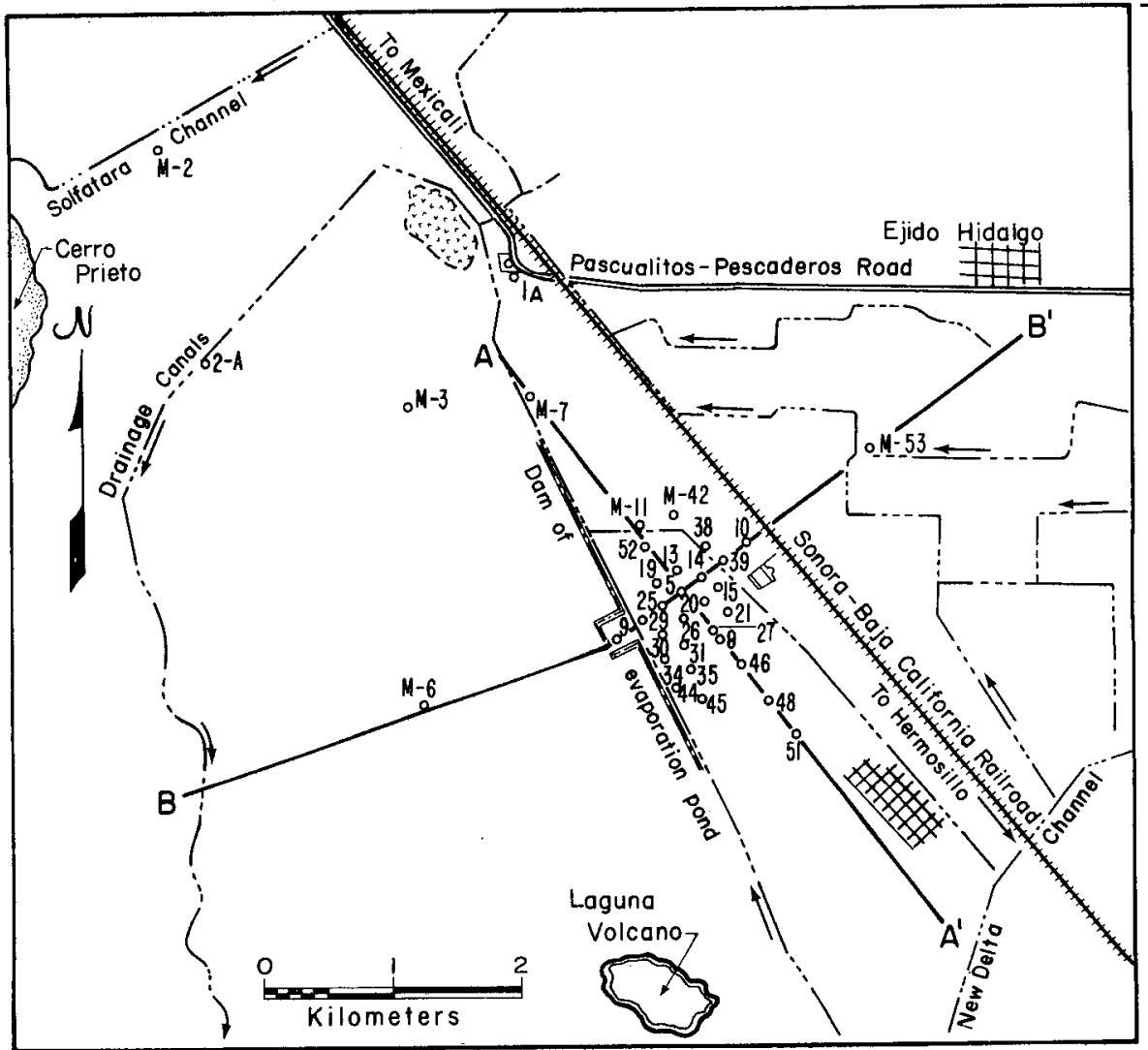

$X 8 L 776-1179$

Figure 4. Location map of exploration and development geothermal wells and section lines $A-A^{\prime}$ and $B-B^{\prime}$; (from Mañon, et.al. ${ }^{15}$ ).
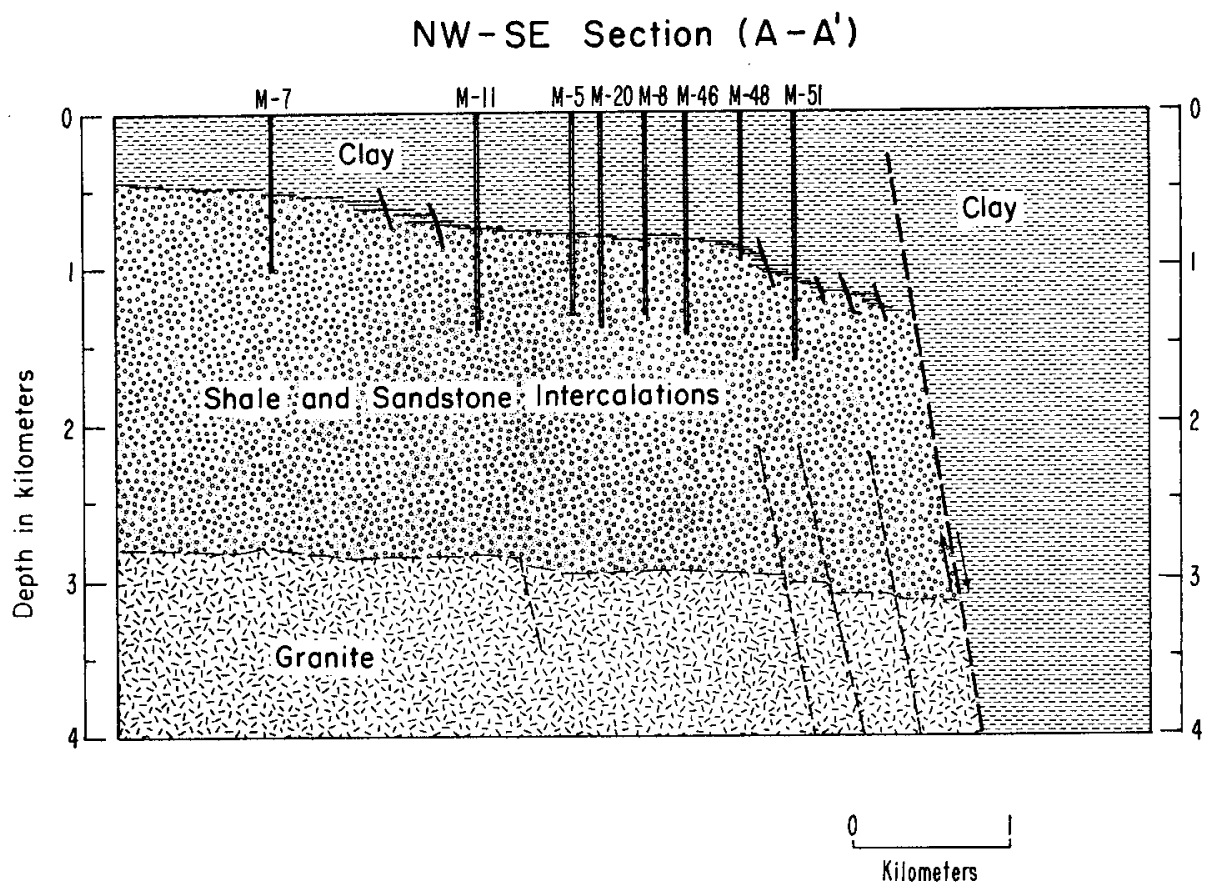

Ing. Salvador Soto Pineda

August 1, 1975

$X B L 776-|18|$

Figure 5. Generalized $A-A^{\prime}$ geological cross section of Cerro Prieto Geothermal Field; (from Mañon, et.al. ${ }^{15}, 1977$ ). 


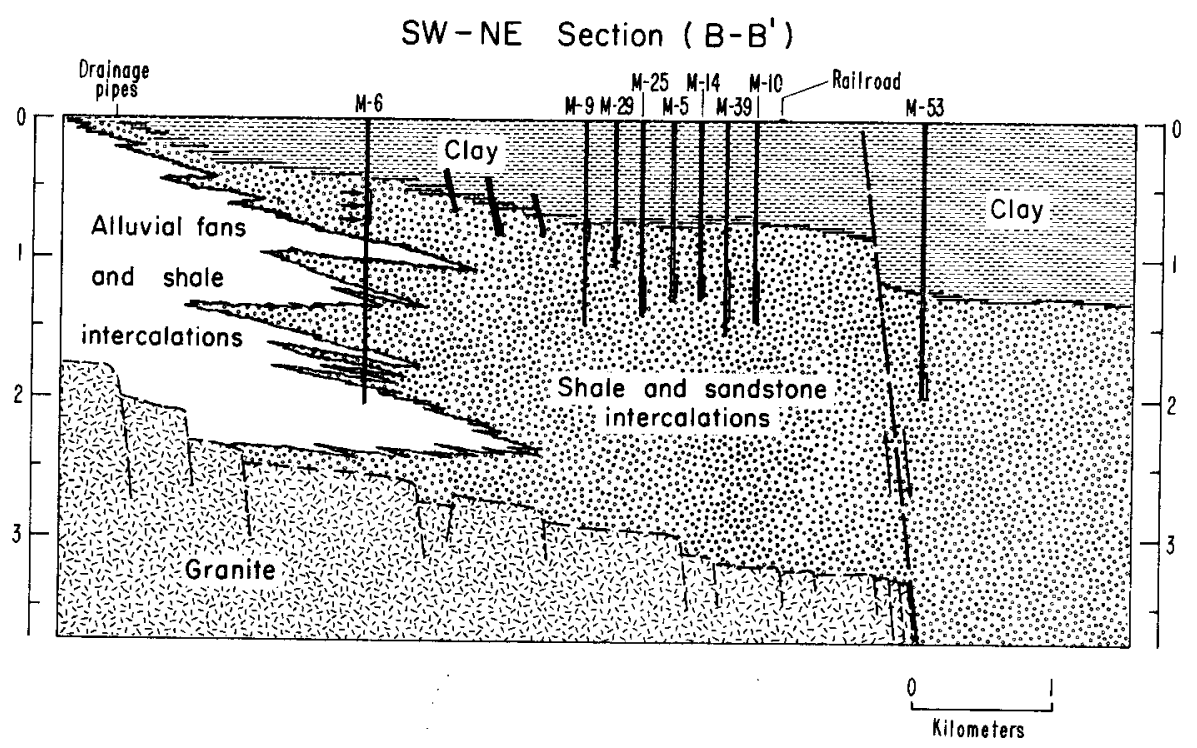

Ing. Salvador Soto Pineda

August I, 1975

$X B L 776-1185$

Figure 6. B-B' generalized geological cross section of Cerro prieto Geothermal Field; (from Mañon, et.al. ${ }^{15}$ ).

SEF PQIFN MAX. CQRERAAIIQN IS .675

FQR A STRETCH $\propto$ F $\quad 1.700$

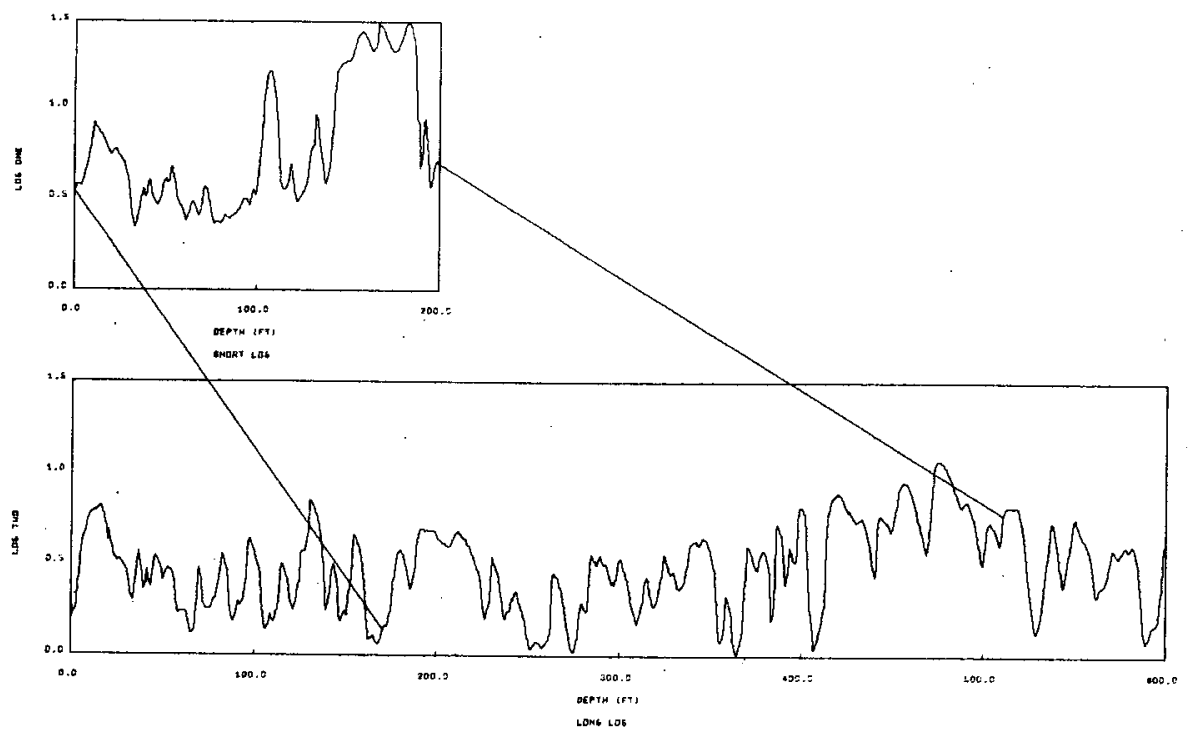

Figure 7. Plot of SP well-log correlation between wells M-9 and $\mathrm{M}-10$ computed by auto-correlation program. 


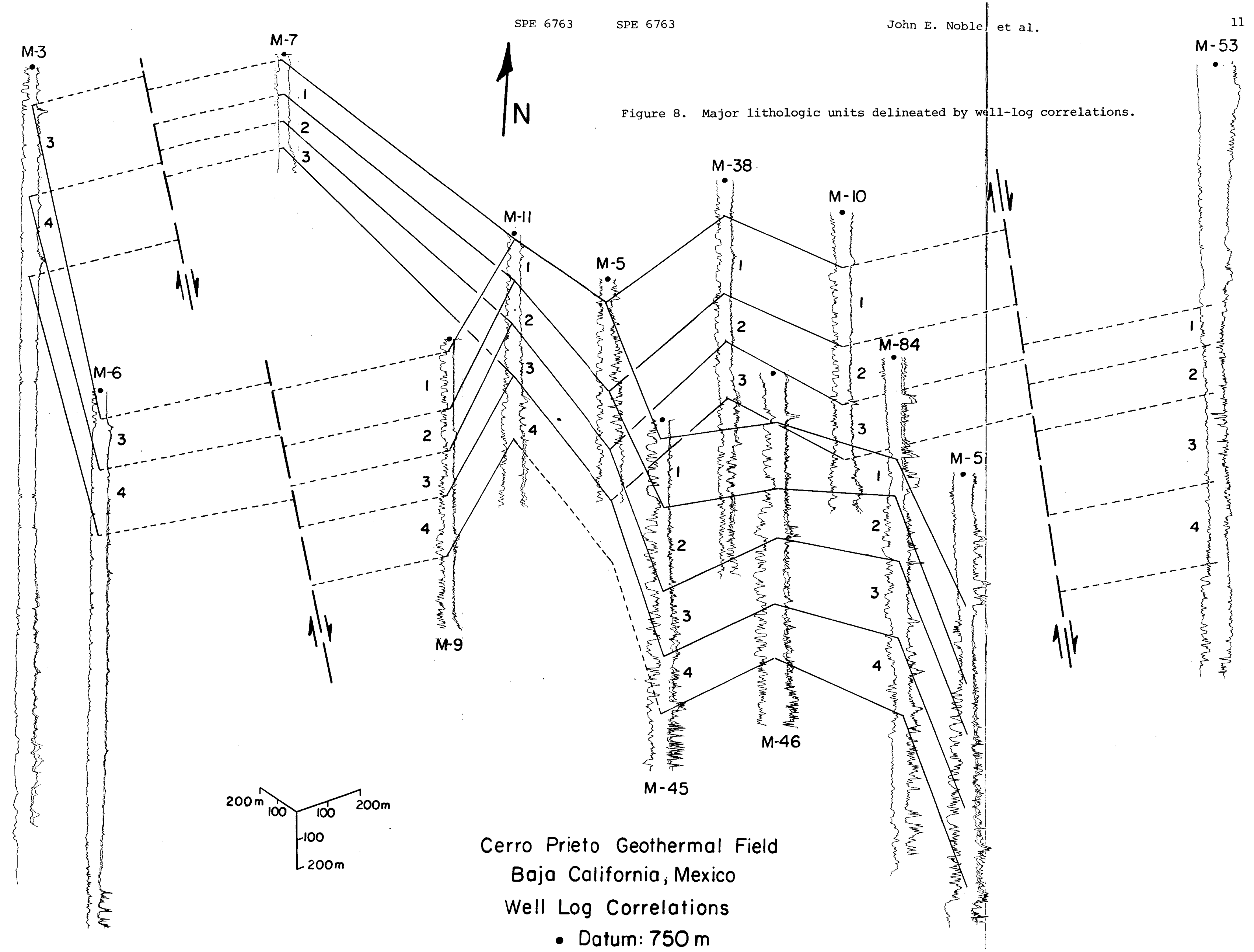




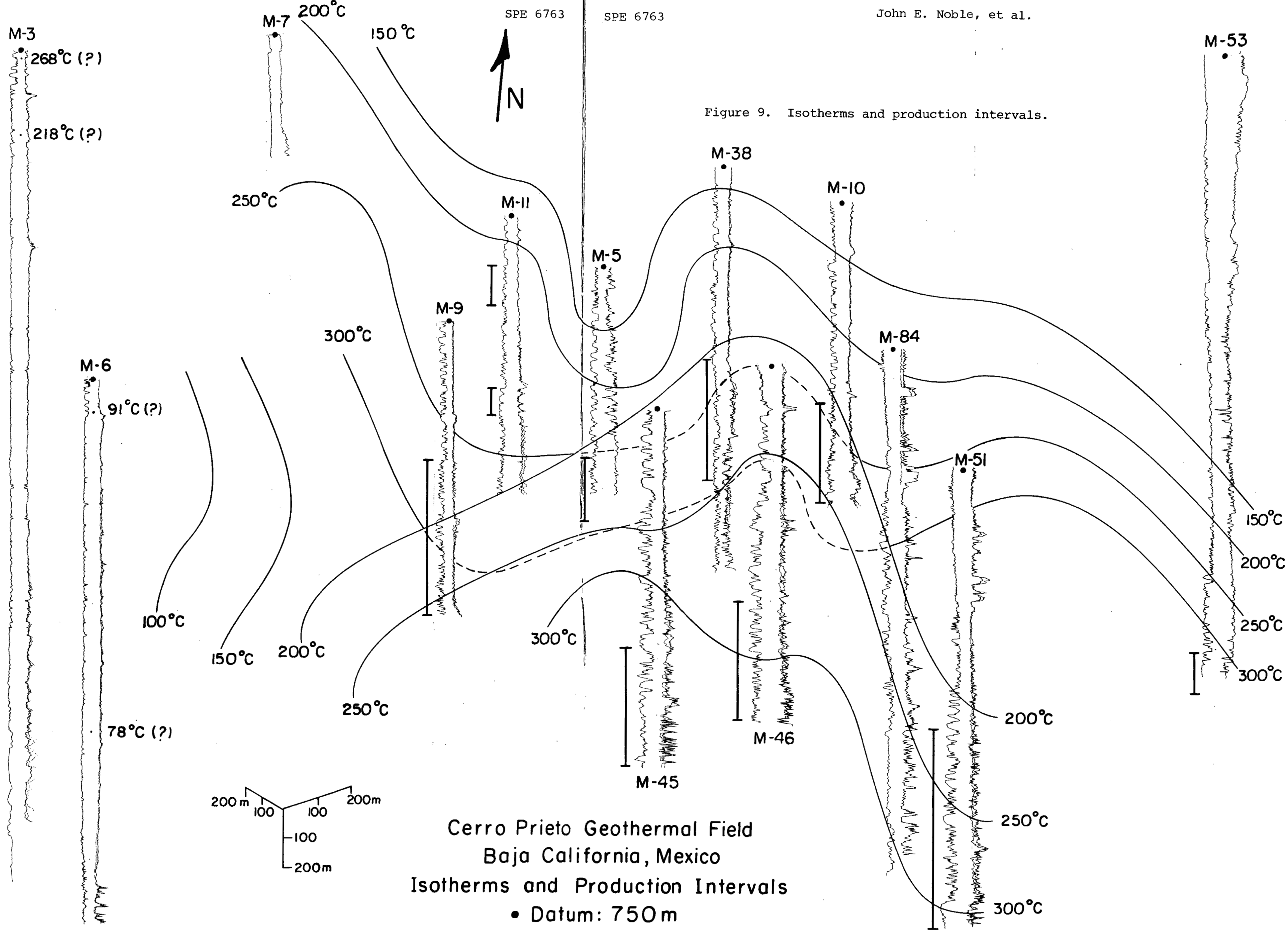



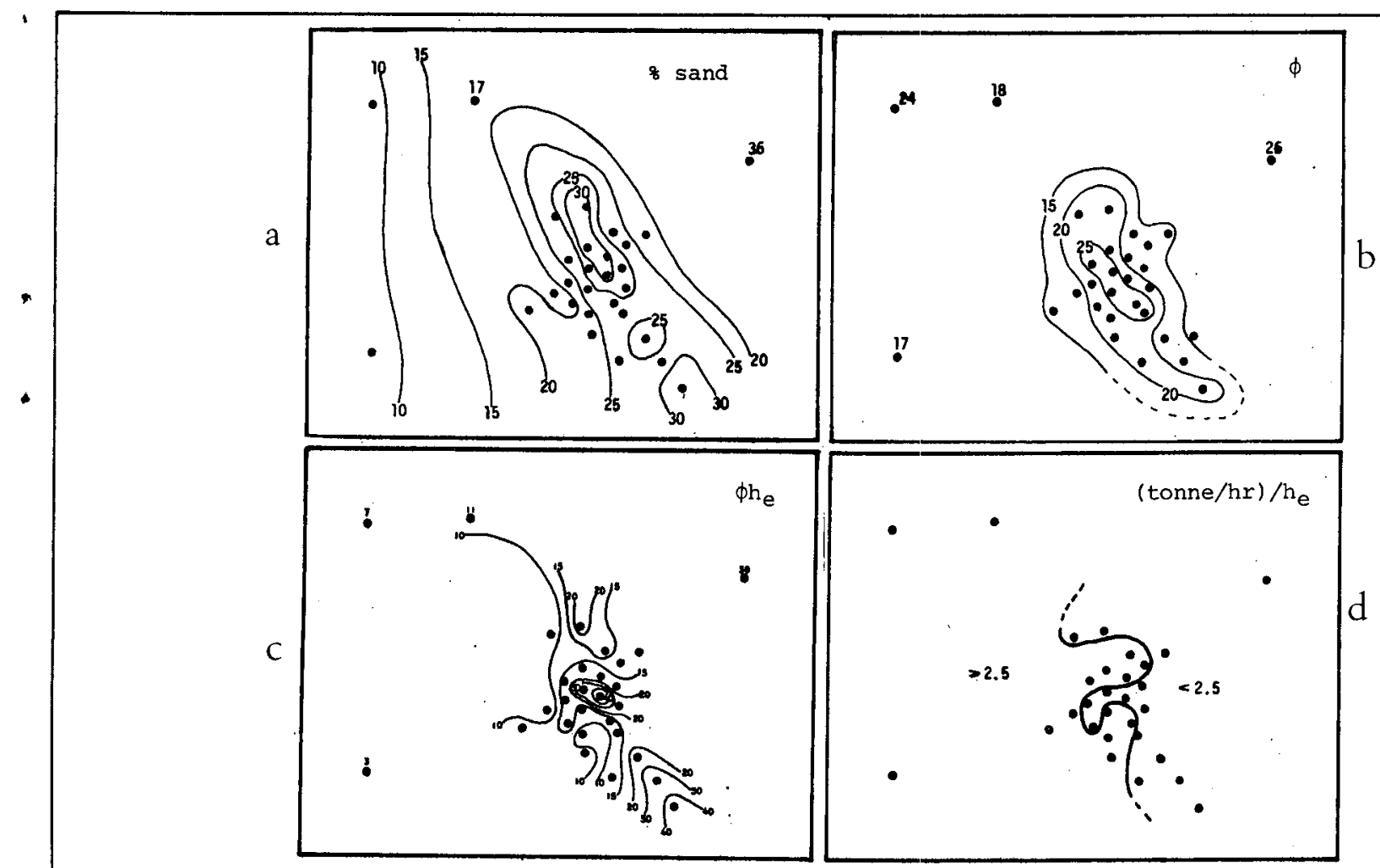

Figure 10. a - Distribution of sand percentages of production intervals.

b - Distribution of porosities of production intervals.

c - Isovols $(\phi h)$.

d - Division of Field by production-to-effective pay thickness ratio 2.5 .
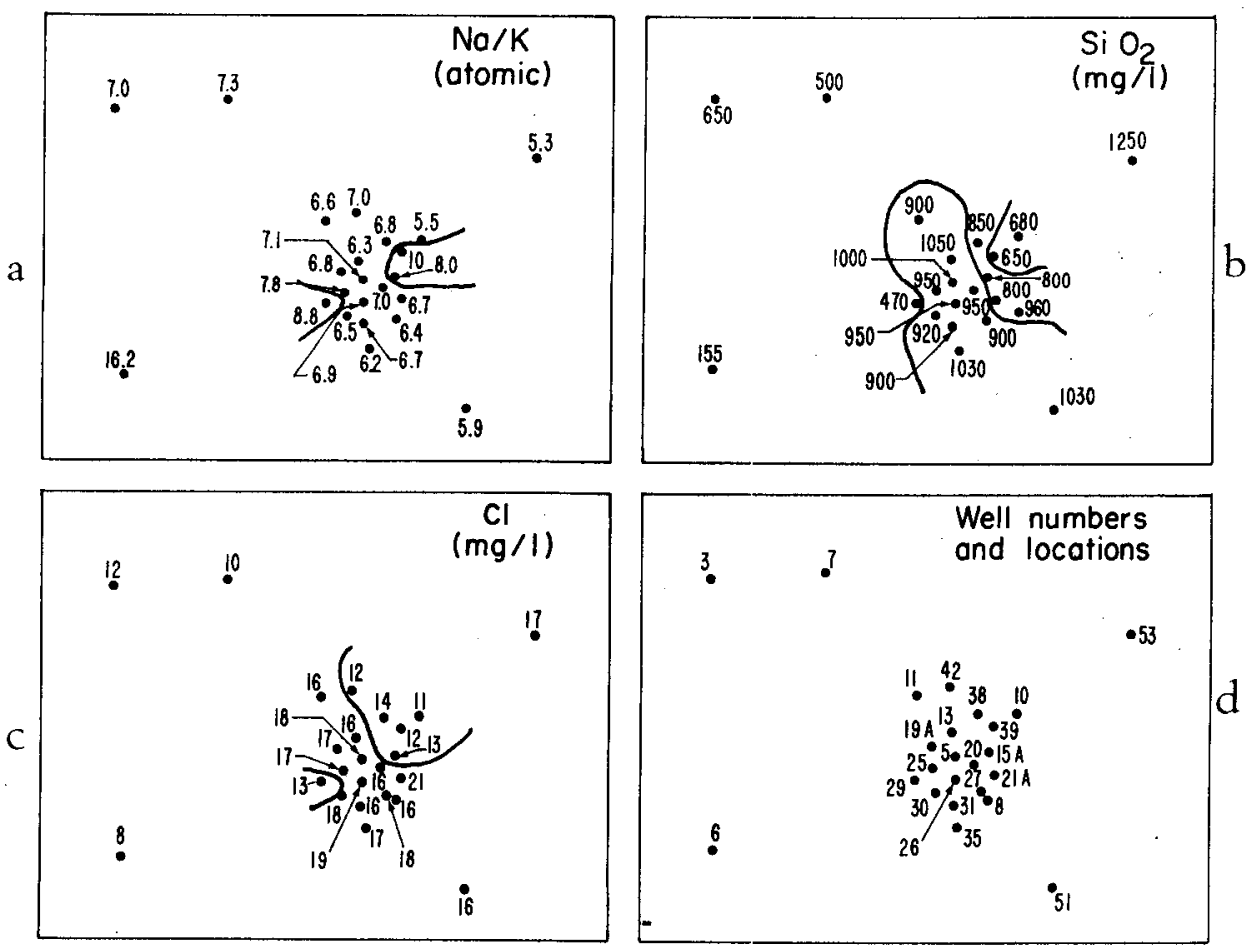

Figure 11. a - Na/K ratio distribution.

b - $\mathrm{SiO}_{2}$ concentration distribution.

c - C1 concentration distribution.

d - Index map of wells analyzed. 